\title{
Saatuse tahtel
}

\author{
Leena Huima
}

\section{Sissejuhatus}

Järgnevas uurimuses on lähtutud sellest, et keel on ühiskonna semiootilise süsteemi üks osa. Aga keel on ka instrument, mille abil semiootilist süsteemi luuakse ja säilitatakse. Ühiskonna semiootiline süsteem väljendub keskselt ajalootõlgenduses ja sellega seostuvates sümbolites. Uurimuse objektiks on valitud üksikinimeste elulood, mis rakendavad semiootilist süsteemi isiklikul tasemel. Materjaliks on eesti naiste trükis välja antud ja toimetatud elulood. Seetõttu kajastavad need võib-olla rohkem kogumike toimetajate kui elulugude autorite keelelisi valikuid. Siiski võib niisugust uurimist pidada põhjendatuks. Elulookogumikud on konkreetsed trükised, mida võib raamatupoest osta ja lugeda. Nad avaldavad mõju sellele, kuidas inimesed tõlgendavad ühiskonna ja enda elu. Nendest saab kollektiivse mälu üks osa.

Ene Kõresaar tõlgendab prantsuse sotsioloogi Maurice Halbwachsi terminit „kollektiivne mälu” mitmepalgelisena mõistena, mis on seotud grupiidentiteediga. Kõresaare järgi struktureerib kollektiivne mälu seda sümbolipagasit, millega grupp opereerib. Niisugune mälu on selektiivne - rekonstrueerib minevikku olevikust lähtudes. Kõresaar liitub nende uurijatega, kes ütlevad, et kirjutatud või jutustatud elulugu ei ole kunagi puhtisiklik, vaid kajastab ühiskonnas ja kultuuris kinnistunud stereotüüpiaid (Kõresaar [2001]).

Kui Ühendus Eesti Elulood algatas 1998. aasta suvel projekti „Sajandi sada elulugu”, saadeti nii kodu- kui ka väliseesti ajalehtedele üleskutse. Kuulutati välja elulugude kogumise võistlus, mille eesmärgiks olevat „koguteos eestlaste saatusest XX sajandil”. Tekstis öeldi:

Teretulnud on kõik kaastööd selle sajandi eri kümnenditel sündinud eestlastelt kuni kõige nooremateni välja: meestelt ja naistelt, linnast ja maalt, kodumaalt ja võõrsilt, kü̈̈ditatutelt ja küüditajatelt, Eesti Leegioni ja Eesti Korpuse meestelt, kirikuõpetajatelt ja kommunistliku partei funktsionääridelt, kohtunikelt ja

\section{http://haldjas.folklore.ee/tagused/nr16/huima.pdf}


karistatutelt, põlluharijatelt ja poliitikutelt, kunstnikelt ja pankuritelt (EE I 2000: 7).

Tekstis nimetatud opositsioonipaarid seostuvad enamasti Teise maailmasõja sündmuste, küüditamiste ja okupatsiooniga. Ka tsiviiltegevusele viitavad opositsioonid, nt kirikuõpetajatelt kommunistliku partei funktsionääridelt, põlluharijatelt - poliitikutelt on afektiivsed, tuletades meelde kirikuõpetajate küüditamisi ja tagakiusamisi partei funktsionääride poolt, taluomanike sundimist kolhoosidesse jmt. Olulised faktid on üleskutse järgi autori lapsepõlv, kodu, ajastu, miljöö, erakondlik kuuluvus, hetkesituatsioon oma elus. Rõhutada tuli „sündmusi, mis on määranud kirjutaja saatuse ja käekäigu".

Ühenduse Eesti Elulood juhatuse pöördumises osavõtjaile (EE: 7-8) on mainitud Saksa sõjaväge, Siberi-aastaid, põgenike lahkumist sügisel 1944. Nendest vaikimist nimetatakse salgamiseks, mis koos hoiatava kolmepunktilise lausega ja enne kui kukk on laulnud... viitab Piiblis kirjeldatud Kristuse ärasalgamisele Peetruse poolt. Tekstis on öeldud, et keelatud elulugusid on muidki: näiteks ei pea keegi parlamendis enesestmõistetavaks nimetada, et kuulus kommunistlikku parteisse. Üleskutset neist kirjutada ei ole siiski sama emotsiooniga välja toodud. On ainult öeldud, et igal inimesel on õigus oma eluloole.

Üleskutses ja pöördumissõnades projitseerub ennast eestlasteks identifitseerivate inimeste raamistik. Võib öelda, et „eesti rahvas" on inimesed, kellel on sama grupiidentiteediga seotud kollektiivne, selektiivselt koostatud mälestusvara.

Eesti praegusele ajalookäsitlusele on omane rahvusliku vaatenurga rõhutamine. Eriti ajaloolane Jüri Kivimäe on kritiseerinud seda, et ajalugu tõlgendatakse kui rahvaajalugu (Volksgeschichte; vt Kivimäe 1999). Ka elulugusid kogudes on rõhutatud seda punkti: kogutakse andmeid eesti rahva saatuse kohta. Peakogumiku tiitel ongi „Eesti rahva elulood”. Kivimäe sõnul on objektiivne ajalookirjutamine Eestis praegu võimatu, kuna avaliku arvamuse survel tuleb ajaloolastel kirjutada nt ajalooõpikud rahvaajaloo seisukohast:

Such needs, however, run into conflict with the criteria of best practice in professional historical research. This tension is clearly reflected in recently published Estonian history textbooks. It is characterised by a strong emphasis on the historical survival of the Estonian people; [---] (Kivimäe 1999: 207). 


\section{Leena Huima}

Niisugune eesmärk on siiski vastuolus parima professionaalse ajaloouurimise kriteeriumidega. Sama pinge on selgelt näha praegusel ajal väljaantud eesti ajalooõpikutes, mida iseloomustab tugev eesti rahva ajaloolise ellujäämise rõhutamine (Kivimäe 1999: 207).

Üks eesti ajaloouurimuse aktuaalseid teemasid on taas küsimus, kas oleks olnud võimalik aastail 1939-1940 midagi teisiti teha. Kas allaandmine ja nõukogude võimu kiire legaliseerimine presidendi allkirjaga oli ainus võimalus või kas allakirjutajad olid oma riigi mahamüüjad ja rahva reetjad? (Kirjandust ja arutlusi selle kohta vt mh Park 1999: 222-223.) Väliseestlastest ajaloolane Toivo U. Raun vastas oma ajalooteoses „Estonia and the Estonians” samale küsimusele aastal 1987:

Nevertheless, it must be asked whether anything the Päts government did in the last weeks of independence would have made any difference regarding Estonia's fate. If one argues from the perspective pf 1940 (and not from hindsight), it did not seem irrational to postulate that the changing fortunes of war yet work in favor of the survival of an independent Estonia if the Estonian people could escape physical devastation. (Raun 1987: 146).

Siiski tuleb küsida, kas miski, mida Pätsi valitsus iseseisvuse viimastel nädalatel tegi, oleks Eesti saatust kuidagi muutnud. Kui argumenteerida 1940. a vaatenurgast (ja mitte praegu tagasivaadates), oli hästi mõttekas postuleering, et vahelduv sõjaõnn võiks veel töötada iseseisva Eesti ellujäämise heaks, kui eesti rahvas pääseks füüsilisest hävitamisest (Raun 1987: 146).

Raun kasutab väljendit Estonia's fate - 'Eesti saatus'. Eestist, eestlastest ja eesti rahvast rääkides on 'saatus' olnud läänemaades väga tavaline mõiste, eriti väliseestlaste ja estofiilide ringkondades. (Näiteks Ants Orase raamat Baltic Eclipse ilmus Soomes nime all Viron kohtalonvuodet - 'Eesti saatuseaastad'). Eesti kirjakeele seletussõnaraamat (1998: V:2) annab sõnale saatus tähenduse ,inimese elukäik, kõik selles toimuv v. toimunu nagu mingi võõra, välise jõu ettemääratuna”. Rauni tekstis on the changing fortunes of war 'vahelduv sõjaõnn' iseseisev subjekt, nagu oleks tegemist omal tahtel tegutsevate jõududega (inglise keeles mitmuses), mis töötaksid iseseisva Eesti ellujäämise heaks (work in favor of the survival of an independent Estonia). Nemad oleksid võinud eesti saatust muuta, Pätsi valitsus aga mitte. 
Praeguses Eestis on rahvaajaloo semiootika suurelt osalt sama kui varasemas väliseesti kultuuris. Üks tähtsamatest stereotüüpiatest tundub olevat EESTI RAHVAL ON SAATUS ehk mingi võõra, välise jõu ettemääratud elukäik, mida võib teatud määral tublidusega trotsida.

Üleskutses elulookirjutamise võistlusele esineb kaks korda sõna saatus. Esimesel korral räägitakse eestlaste saatusest, mille taustal kajastub kollektiivse rahvasaatuse mõiste, teisel korral sündmustest, mis on määranud kirjutaja saatuse - nagu oleksid ka sündmused iseseisvad jõud, mis inimese elukäiku määravad.

Kinnistunud stereotüüpide väljendamine tingib ka kinnistunud märgisüsteemi. Teatud mõttes on kõik keelendid stereotüübid: nende korduvus üldtuntud kontekstides on eeldus sellele, et neid tõlgendatakse „õigesti” - muidu ei oleks inimestevaheline kommunikatsioon üldse võimalik.

Siin uurimuses otsitakse keelelisi stereotüüpe, osalt metafoore, mis nii väljendavad kui ka täiendavad ja arendavad kollektiivse mälu sümbolipagasit ja struktuuri. Otsitakse vastust küsimusele, kuidas kirjutaja ise oma elu tõlgendab ja oma isiklikku ajalugu struktureerib. Kas sündmused määravad meie saatuse ja käekäigu, nagu ütleb üleskutse? Või kas on määraja mingi personaalne jõud, näiteks Jumal? Kuidas eesti naised ennast identifitseerivad? Kas sündmuste ohvriteks või iseseisvateks otsustajateks? Kas eesti ja soome naiste vahel on selles suhtes erinevusi?

Sada aastat tagasi oli nii Eestis kui ka Soomes valdav religioon luterlik ristiusk. Usuõpetust anti rahvakoolis ning leeris. Rahvakooli usuõpetuse põhiosaks olid Vana Testamendi inimeste elulood ja Jeesuse mõistujutud, leeris õpetati katekismust. Nii koolis kui ka leeris õpetati, et taevas on Jumal, kes inimeste elu juhib ja kaitseb. Tema poole palvetatakse, st ta käest palutakse igasugust head ja teda tänatakse. Vana Testamendi elulugude sageli korduv õpetus oli see, et inimene võib sattuda väga pingelisse olukorda, aga siiski juhtub kõik tema elus Jumala tahtel.

Nii Eestis kui ka Soomes oli jumalausk varem üldine kultuuriline raam ja konventsionaalsete mõistete kogu, mis ei tähenda ilmtingimata, et inimesed väga suurel määral oleksid seda isiklikult tõeks pidanud. On ilmne, et Eestis oli õhkkond selles mõttes liberaalsem juba 19. sajandil ja 20. sajandi alguses; Soomes oli kristlik kultuur ühtlasem. Soomes jäi obligatoorne usuõpetus alles ka pärast Teist maailmasõda, Eesti koolides lõpetati usuõpetus 


\section{Leena Huima}

ära. Ka leeris käimine muutus Eestis haruldaseks; Soomes käib leeris ikka veel umbes $90 \%$ rahvustikust. Eriti huvipakkuv on niisiis see, mil määral on jumalausu konventsioonid eesti inimeste kollektiivses teadvuses edasi elanud.

\section{Materjal}

Eestlaste elulugudega tutvudes saab selgeks, et mehed annavad naistest harvem oma elule hinnanguid. Naiste elulugudele on omasem elu kui terviku üle arutlemine. Sellepärast on siin piirdutud naiste elulugudega. See ei tähenda, et samu teemasid ei tasuks ka meeste elulugudes jälgida. Ka mõlema rühma omavaheline võrdlemine nendel teemadel pakuks kindlasti huvi.

Põhimaterjaliks on olnud kogumik Eesti elulood. Naised kõnelevad (NK), mis ilmus aastal 1997. Kuna kogumikus on ainult 12 elulugu, on materjali täiendatud kogumikes Eesti rahva elulood (EE I 2000; EE II 2000) ja Kured läinud, kurjad ilmad (KL 1997) ilmunud naiste elulugudega. Siiski on NK-d peetud primaarseks allikaks kahel põhjusel: 1) tekstide stiili ja sõnastuse varieeruvus on suurem kui EE-s, mis võiks tähendada, et toimetamise osa on NK-s väiksem ja et kirjutised on käsikirjadele lähedasemad (peale selle on EE-s ka intervjuud); 2) kogumiku koostamise lähtekohaks oli tuua esile just nimelt naiste arusaamad ja väärtushinnangud (NK 1997: 6).

Kontrastiivse aspekti esiletoomiseks on toodud näiteid ka soome naiste elulugukogumikust Satasärmäinen nainen (SN 1992).

Materjalist on otsitud ja analüüsitud tekste, kus inimese kogu elu või üksikuid elujuhte seletatakse mingi välise jõu tegevusega. Üksikjuhtumite puhul on mõnikord raske öelda, kas tegemist on metafooridega või mitte. (Kui hakkab paduvihma sadama ja öeldakse taevaluugid läksid lahti, siis on tegemist metafooriga juhul, kui keegi nii ei usu - aga kui usutakse, et taevakaanes on tõesti luugid, ei olegi see enam metafoor.) Siin ei ole tõmmatud piiri metafooride ja mittemetafooride vahele. On lähtutud sellest, et laias mõttes on tegemist müütilise metafooriga, mille tüüpiline joon on põhimetafooride esinemine kahes vormis: sõnastusena ja sümbolitena (Siikala 1992). Kui keegi räägib saatusest kui jumalast, kellel on tahe ja kes tegutseb, on vastav jõud mingil määral ikkagi rääkija mõistesüsteemis ka sümboli tasemel olemas. 


\section{Elukäigule mõjuvad personifitseeritud jõud}

Selles peatükis on vaadeldud, mis sündmused või jõud on tekstide järgi määranud, juhtinud või muutnud inimese või inimkollektiivi elukäiku, käitudes inimeste või vaimude sarnaselt. Näiteis on abstraktsel nimisõnal lauses teadlikult toimiva, oma tegevust kontrolliva osalise ehk agendi roll (vt EKG II 1993: 474 §) - tegemist on niisiis abstraktse mõiste personifitseerimisega.

I. Aktiivseks toimijaks on sõda. Näiteid sellest on ainult üks. Öeldisverbid on transitiivsed (väljaarvatud käituma) ja tähendavad mingi olukorra muutmist teiseks. Antropomorfsus on märgatav. Sõda süüdistatakse isegi selles, et ta käitub ebahumaanselt(!):

(1) Sõda on palju inimhingesid muutnud, nii palju kurbust südamesse istutanud, nii palju kauneid mälestusi matnud, röövinud meie au, uhkuse, vabanduse, tuhastanud suurema osa meie suguvõsast, ebahumaanselt käitunud meie omastega (NK 1997: 31; 2; snd 1928; Austr).

II. Aktiivseks toimijaks on elu. Tavaliselt on elu intransitiivse lause (mitteteadlik) subjekt, millel juhul autor ise ei ole lauses märgitud (sellest hiljem). Veidi haruldasemad on niisugused näited nagu siin, kus elu on tegevussubjekt ja autor tegevusobjekt, st elu on aktiivne ja autor passiivne - elu tegevus muudab midagi autori suhtes. (Kahes näitelauses ei ole autori roll sõnadega väljendatud, aga siiski selge: hiljem aga elu muserdas [mind/meid]; elu ise on andnud [mulle] vastuse.)

(2) Elu Peetriga oli siiski õnnelik esimesed viis aastat, hiljem aga elu muserdas ja me ei leidnudki enam teed teineteiseni. [---] Ja alles peale mehe õudset surma sain hiljem aru, miks mees kunagi ei nõustunud lahutusega, kuigi seda talle pakkusin, kui elu oli mulle talumatuks muutunud - see oli siiski suur armastus, mille elu mulle kinkis. (NK 1997: 90-91; snd 1931)

(3) Kui minult küsitaks, kes või mis on mind aidanud elu rasketel hetkedel, siis elu ise on andnud vastuse. Kui mind koolist välja visati, elasin seda üle kergelt, sest leidsin sel ajal oma Suure Armastuse; kui see ei pannud elutormidele vastu, aitas mind Esimene Mees oma võimete kohaselt; kui aga tema muutus eikellekski, olin jõudnud armuda (KL 1997: 148; snd 1935). 


\section{Leena Huima}

III. Aktiivseks toimijaks on sündmused ja ajajärgud. Kuigi siin on vaadeldud ainult naiste kirjutisi, tuleb siin teha üks vajalik erand. Meestele paistavad olevat omased väljendid, kus tegevused, sündmused või ajajärgud personifitseeritakse. Naistelt leiab neid päris harva. Sündmused on väga tihti sõnastatud metonüümiliselt: 14. juuni 1941 tähendab 'kõik see, mis toimus 14. juunil 1941'. Mehed on niisiis väga sõnasõnaliselt vastanud üleskutsele, s.t kirjutanud sündmustest, mis on määranud nende saatuse. Kõik järgnevad kolm näidet on meestelt:

(4) 1938. aasta sügis tõi meie majja ootamatu kaotusevalu ja leina (EE I 2000: 265; snd 1921).

(5) See ametikoht kinkis mulle ka mu elu suurhetke (EE II 2000: 240; snd 1937).

(6) Ja siis tuli saatuslik 14. juuni 1941, mis hävitas meie pere (EE II 2000: 210; snd 1936).

IV. Aktiivseks toimijaks on saatus. Kõige tavalisem välise jõu nimetus, mis ka reeglipäraselt agendi rollis esineb, on Eesti naiste elulugudes saatus (või siis suure algtähega Saatus). Soome keele vastavat sõna kohtalo ei leidu soome naiste elulugude kogumikus üldse.

Eesti tekstides on saatusel väga sageli omadused, mis kristluses on seotud Jumalaga, näiteks:

\section{Etteteadmine}

(7) Jah, see olin mina, Maimu, kes ma sündisin köögitruubi taguses toas 1935. a. sügisel. Nüüd on see päev kuulutatud hingedepäevaks. Siis sellest suurt ei räägitud, aga Saatus oleks nagu teadnud, et mul tuleb elust lahkunud lähedastega kurbi hüvastijätte varakult üle elada... (NK 1997: 121; snd 1935.)

\section{Kaitsmine}

(8) Midagi kohutavamat kui oma perest lahkujäämine ei osanud ma ette kujutada [kui olid alanud küüditamised]. Kuid hea saatus kaitses meid seegi kord (EE II 2000: 171; snd 1935).

\section{Tahtmine}

(9) Tutvus Karliga arenes armastuseks ja oleks viinud vist abiellumiseni, kui saatus poleks tahtnud teisiti (EE II 2000: 173; snd 1935). 
(10) Saatuse tahtel laulis just sel õhtul kirikus Kõrgemate Koolide Segakoor, kus me professor Karindi käe all koos abikaasaga mitu aastat laulsime (EE II 2000: 182; snd 1935).

\section{Kinkimine}

(11) Saatus hakkas mulle järjest kingitusi tegema. Ma kohtasin oilsat meest, kes kõige raskemal ajal ulatas mulle abistava käe. [---] Tänu temale langesid kohe ära kõik majanduslikud, olmelised ja muud mured (EE II 2000: 263; snd 1937).

\section{Saatust tänatakse ja temalt palutakse}

(12) Tänan saatust selle imelise hetke eest (NK 1997: 75; snd 1928).

(13) Nüüd paluksin Saatuselt vaid tervist, sest selle väärtuseta kaotavad kõik maailma aarded oma võlu (EE II 2000: 264; snd 1937).

\section{Saatus lööb}

(14) Kuid nüüd jõuan oma elu kõige kurvemate lehekülgede juurde. Veel ei olnud Saatusel mõót täis, veel oli tal minu jaoks hoope jagada. Ja nüüd tuli see nii, et pidi mu otse maad ligi suruma (NK 1997: 127; snd 1935).

\section{Saatusega maadeldakse ja teda trotsitakse}

(15) Mida tähendab elada naisena eesti ühiskonnas? Palju tööd, kannatlikkust, talumisvõimet ja vastupidavust igal juhul, mõeldes alati, et ei tohi saatuselöökide puhul alla anda, vaid ennast jälle sirgu ajada (NK 1997: 129; snd 1935).

(16) Momendil olen Saatusega rahujalal. Aga kui muudab meelt, üritan teda veel trotsida. Ja kui ei suuda enam sedagi, tänan teda kõige kaunima kingituse, minu õnnesädemete ahela eest.(EE II 2000: 264; snd 1937).

\section{Saatusel võivad olla ka emotsioonid nagu inimesel}

(17) Ilmselt juba minu sünnimomendil juhtus saatusel olema paha tuju, sest miks muidu hakkas mu elu kohe kiiva kiskuma (NK; 132; 8; snd 1936).

V. Aktiivseks toimijaks on Jumal. Jumalast traditsionaalses mõttes räägitakse harva. Isegi EE kirikuõpetajate elulugudes ei 


\section{Leena Huima}

ole sõnastatud niisugust tõlgendust elust ja saatusest, et midagi oleks toimunud Jumala tahtel või juhtimisel. Väliseestlased räägivad Jumalast rohkem, nagu järgmine Austraaliasse elama asunud naine, kellel ka saatus tähendab Jumala tahtmisel juhtunut:

(18) Ei tea siin ilmas ühtgi inimest, kelle elulugu ja elutöö ning unistused oleksid sama rada käinud. Inimene unistab, otsustab, aga Jumal juhib. Oma saatuse vastu ei saa mitte keegi, peab alistuma tema tahtele (NK 1997: 31; snd 1928).

Üks NK autoritest väljendab selgelt usku Jumalasse (näited 1920):

(19) Olin põlvili mättal, nutsin kibedasti ja palusin Jumalat, et ta mu ema tagasi tooks (NK 1997: 96; snd 1934).

(20) Mõtetes pöördun alati Taevaisa poole, et minu külmkapp ja televiisor vastu peaksid, vastasel juhul oleks täitsa lõpp, sest televiisori rikkiminek tähendaks ju minu ainukese meelistegevuse, seebikate vaatamise lõppu (NK 1997: 119; snd 1934).

(21) Igat päeva võtan nagu Issanda õnnistust ja palun mõttes ja ôhtul enne magama jäämist, et Jumal annaks mulle ikka tervist, et saaksin veel nüüd elu nautida, sest kogu eelmine elu oli ju minu jaoks ainult kannatuste rada (NK 1997: 120; snd 1934).

Kuigi ta on NK autoritest kõige traditsionaalsem usklik, ei maini ta kordagi seda, et miski tema elus oleks toimunud Jumala tahtel. Ka järgmine autor, kes mainib Jumalat ühe korra (väikese algustähega!), paistab rohkem seostavat Jumalat - või mingit muud impersonaalset jõudu - andmisega:

(22) Annaks jumal või kes iganes (ma ju paraku ole usklik) talle ainult mõistust ja tervist, muu tuleb iseenesest (NK 1997: 242; snd 1958).

Lisaks mainitakse NK-s jumalat fraseologismis jumal teab:

(23) Et mul prantsuse keelest aimugi polnud, kirjutasin kataloogist huupi välja ükskõik mida. Polnud siis ime, et Kristine sageli naerma pahvatas, kui raamatu tiitellehte nägi. Jumal teab, mida kõike ma talle lugeda võisin tuua (NK 1997: 21; 1; snd 1910).

Peale ühe väliseesti autori ei seleta niisiis NK autorid oma elu käiku Jumala juhtimise abil. Jumalast räägivad ainult üks usklik, üks väliseestlane ja autoritest noorim (snd 1954). Ka EE-s tõlgen- 
davad oma elu sündmused Jumala juhtimiseks rohkem väliseestlased ja nooremad (ühevõrra mehed ja naised). Näiteks 1954 sündinud naise seletus oma abikaasa üllatava kojutuleku kohta:

(24) Kui Ülo kolmanda päeva hommikul ootamatult tuppa marssis, pidin peaaegu minestama. Õnn oli sedavõrd suur. Selgus, et ta saadeti Kohtla-Järvelt kogunemispunktist tagasi [Tšernobõli minemast], kuna peres oli kolm last ja tema sõjaväeline eriala ei sobinud antud operatsiooniks. Nüüdseks võin liialdamata öelda, et Jumal hoidis meid tookord (EE II 2000: 416; snd 1954).

KL-s on üks Jumalasse uskuja, kuigi mitte päris traditsiooniline, sündinud 1943. Ka tema räägib Jumalast muust vaatenurgast, mitte Jumala tahtest:

(25) Olen elanud kõik etapid elus nii, et ühtki vastumeelset ettevõtmist pole olnud. Olen oma pika, põneva elu jooksul õppinud ennast armastama. Usun ennast, usun Loojat. Hommikul, kui ärkan, tänan teda ilusa öö eest. Naerdes räägin kõigi oma keha osadega (KL; snd 1943).

1920. või 1930. aastatel sündinud naisi on kogu materjalis (NK + KL + EE I-II) kokku 50. Nad moodustavad ülekaalukalt suurima vanuserühma. Selle rühma noorpõlves käidi veel leeris ja saadi koolis usuõpetust. Võiks arvata, et mõni nendest tõlgendab oma elusündmusi ka 'Jumala' mõiste abil. Siiski peab Jumalat otsima nooremate kirjutistest. Kui 1920. ja 1930. aastatel sündinud põlvkond tahab oma elu sündmusi ja kogemusi mingi välise, personifitseeritud jõu abil seletada, on niisuguse jõu kõige tavalisem nimetus Saatus.

\section{Elukäigule mõjuvad impersonaaliga väljendatud jõud}

Passiiviga väljendatud umbisikuline tegevus on üks võimalus viidata subjektile teda nimetamata. Impersonaal viitab tegevuse olemasolevale, kuid täpsemalt konkretiseerimata elusale sooritajale (EKG II 1993: § 490). Jumala tegevuse puhul on niisugune kõneviis tavaline: lind on loodud lendama ja inimene tööd tegema; teie patud antakse andeks. Siin on vaadeldud juhtumeid, kus lause loogiline sisu nõuab inimesest väljas- ja ülalpool olevat sooritajat, 


\section{Leena Huima}

kellel on võimalik kinkida aastaid, määrata eluteed jmt. Grammatilise vormi järgi on ta elus - tegemist on niisiis personifitseeritud jõuga. Öeldiseks on näiteis määrama, andma, juhtima (mis on kõik väga tüüpilised konventsionaalselt Jumala tegevusega seotud verbid):

(26) Mina teadsin sellest suhtest [teisest naisest] umbes aasta varem, nii kaua ta oligi olnud. Ja justkui püüdis vahepeal seda ka lõpetada, aga ju siis polnud see niimoodi määratud (NK 1997: 196; snd 1941).

Üks KL autoritest kasutab passiiviväljendit päris reeglipäraselt, nagu väljendaks ta järjekordselt usku, et asjad tõesti määratakse ette kuskil väljaspool. Isegi piiblitsitaat on tal passiivis (näide 27), kuigi passiivivorm on antud ei esine üheski eesti piiblitõlkes. Piiblitõlkeis on kasutatud lausetüüpi aeg on last saada (uuemais tõlkeis sündida) ja aeg on surra:

(27) Aga piibelgi ütleb, et aeg on antud elada ja aeg on antud surra, ja küllap ta nii on (KL 1997: 123; snd 1929).

(28) Ükskord oli ta [tuberkuloosihaige abimees] endast väga väljas ja lausa nuttis ja palus, et talle antaks kolm aastatki veel elada, et poisid saaks suuremaks (KL 1997: 120; snd 1929).

(29) Mida oleks tahtnud teisiti teha, kui ma oma elule tagasi mõtlen. Oleks tahtnud ühe raseduse nii üle elada, et ma oleks koos mehega oodanud meie last ja rõõmustanud väga selle üle. Aga nii pole mul olnud, seda rõõmu pole mulle antud, sest mõlemad mu pojad on sündinud nagu "enneaega", ja sellest on kole kahju. Aga mis teha, mõni rõõm peab inimesel saamata jääma, elu on kord selline (KL 1997: 127; snd 1929).

Samasugused väljendid leiduvad ka EE-s:

(30) Püüan kirja panna, milline oli tee, mis mulle oli määratud käia Sinuta (EE II 2000:148; snd 1933).

(31) Vahetevahel ma mõtlen, et mind on tõesti kusagilt kõrgemalt poolt juhitud, kuna mu saatus keeras tollel 15. aprillil astrofüüsika poole (EE II 2000: 339; snd 1944).

Ilma subjektita läheb on piirjuhtum, mis kuulub ühelt poolt eeltooduga kokku: subjekti võib pidada ebamääraseks, seega sama- 
suguseks kui passiivilauses. Teiselt poolt võiks olla mõeldav, et tegemist on ellipsiga, kus subjekt elu on ära jäetud:

(32) Tütar õppis muusikakoolis viiulit. Temast loodeti head viiuldajat. Kuid ei saanud. Mõnikord läheb vastuoksa: temast sai poemüüja ning kahe väikese, vallatusest pakatava tüdruku ema (NK 1997: 139; snd 1936).

\section{Iseseisva liikuja metafoorid}

Elu võib olla subjektiks ka intransitiivlauses, väljendades tegevust, mis ei mõju vahetult muile kui subjektile endale ja mis toimub subjekti enda jõul. Koos intransitiivse verbiga on elu kui tegevussubjekt iseseisev liikuja või muutuja, mis ei muuda autori seisundit. Ka autor ei ole võimeline elu tegevust peatama või muutma. Et tegemist on autori eluga, mida ei saa temast endast eristada, tekib loogiline vastuolu. Niisugune väljendusviis rõhutab autoripoolsete mõjutamisvõimaluste minimaalsust - ehk seda, et mingi võõras, väline jõud oleks nagu elu ette määranud.

Eesti tekstides kasutatakse elu kohta õige sageli väljendit elu läheb/ läks edasi. Tavaliselt öeldakse nii pärast traagilist või rasket kogemust. Struktuuriliselt paigutatakse lause harilikult kohta, mis märgib uue ajajärgu algamist - nagu oleks elu hetkeks peatunud ja siis läheks jälle edasi. Väga tavaliselt on see lõigu esimene lause. Näites (33) räägitakse abielulahutusest, näites (34) on haruldasem kasutus: öeldis on olevikuvormis, seos minevikuga on nõrgem. Väljend on fraseologismi piiril, aga mitte päris fraseologism, sest nagu tekstist nähtub, laiendite juurdepaigutamine ja keelekujundi täiendamine on võimalik. Tegemist on siiski varematest näidetest märgatavalt selgemalt metafoorilise ning kaugele idiomaatistunud väljendiga.

(33) Elu läks edasi, küll olen ma raskeid päevi näinud, aga ma olen alati toime tulnud (NK 1997: 170; snd 1938).

(34) Elu läheb kiirel sammul, peatumatult edasi. Mul on tunne, et mu mees ei ole lahkunud, vaid elab iga päev mu kõrval edasi, kuigi ma teda ei näe (EE II 2000: 41; snd 1926).

Elu läheb esineb ka koos laiendiga, mis vastab küsimusele kuidas?. Järgnevas näites kinnitab tähelepanu kerge pinge autori 


\section{Leena Huima}

kahe hinnangu vahel: ei läinud nii, nagu oleks pidanud minema ja ei läinud nii, nagu ma tahtnud oleksin - nagu tahaks autor küsida, kas elu peab või ei pea minema tema enda tahte järgi:

(35) Oma tulevase abikaasaga tutvusin, kui olin 22-aastane. Mulle tundus, et tema on see õige. Nüüd, 36 aastat hiljem, kus me juba 14 aastat lahutatud oleme, mõtlen ma, et kuigi elu ei läinud nii, nagu oleks pidanud minema või nagu ma tahtnud oleksin, oli mul tookord vist siiski õigus (NK 1997:164; snd 1938).

Iseseisva liikujana võib elu ka veerema minna. Sel juhul on elu agendiroll nõrk ja läheneb neutraalile - veerema minemine ei sõltu tavaliselt veereja tahtest, vähemalt siis, kui veeremine on juba alanud.

(36) Vahetasime mitu korda elukohta, et jätta mehe armukesi maha. Ta ise tahtis seda, sest teatud mõttes oli ta minu üle uhke. Kuid elu oli nii veerema läinud ja viimaks leidis ta kellegi, kellega mõtles uuesti alata (NK 1997: 79; snd 1928).

Verbi veerema tähenduses on kaks olulist külge: 1) miski läheb veerema välise energia abil; 2) veeremist on raske või võimatu peatada. Näites (37) veerevad sõjalained, näites (38) sõjavankrid. Personifitseerimise asemel on jõud ('sõda') konkretiseeritud metafooriliselt, loodusejõududele viitavalt (on ka võimalik, et vanker seostub siin üle taevakaane sõitva äikesejumaluse vankriga).

(37) 1943-44 veeresid aga sõjalained üle meie väikese Eesti. Tuli meilgi aeg jätta kodu ja minna sõjapakku (NK 1997: 142; snd 1939).

(38) Jälle veeres sõjavanker üle Eestimaa (NK 1997: 59; snd 1929).

Veerema kasutamine saatuslike jõudude tegevuse väljendamisel võiks viidata sellele, et eesti naiste elulugudes on välise jõu peatamatus selle üks keskseid dimensioone. Eesti ja soome elulood on struktuuriliselt erinevad: eesti elulood edenevad tavaliselt kiirelt ja peatumata lapsepõlvest vanaduspõlve. Soome naiste elulugudes on sagedased kohad, kus autor peatub ja vaatab tagasi minevikule, arutleb juhtunu üle ja annab selle kohta hinnangu. Sündmuste järjekord ei ole ilmtingimata kronoloogiline.)

Saatus tähenduses 'elukäik' esineb suhteliselt harva. Tavaliselt seletatakse 'saatuse' mõiste abil seda, et elu on läinud teisiti kui autor oleks tahtnud: 
(39) Siis tundub see korter kindlasti tarbetult suurena ja kõledana. Aga kui lapsed oma peredega mõnikord kõik korraga koju tulevad, siis on ruumi kõigile, Loodan, et nad ikka tulevad. Ja tundub, et muid lootusi ja igatsusi enam ei saagi olla. Ega ei tahaks sellega päriselt leppida, aga ma pole ka väga rahulolematu. Ju see on siis mu saatus (NK 1997: 199; snd 1941).

Ka saatus võib olla metafoorne liikuja. Järgnevas näites tabab saatus nagu rakett või välk, mingi välise jõu poolt eluteele saadetud:

(40) Siis tabas minu vanemaid karm saatus. Minu vend, kes oli nüüd diplomeeritud röntgentehnik, 29 aastat vana ja kihlatud, läks ühel maihommikul tööle kuninglikku haiglasse. Tööle asudes puudutas ta üht rikkiläinud röntgeniaparaati ning suure tugevusega vool läbis tema keha (NK 1997: 49; snd 1928; Austr).

\section{Oma elukäigu hindamine}

Nagu eeltoodud näiteist selgelt nähtub, viitavad eesti autorid 'saatusele' või millelegi nimetamata välisele jõule, sageli seletamaks ja vabandamaks seda, et elu ei läinud nagu oleks pidanud: saatus tahtis teisiti; polnud see niimoodi määratud. Järgnevas on võrreldud eesti ja soome naiste elulugusid ning otsitud vastust küsimusele, kas inimese saatus on autorite arvates ainult väliste jõudude käes või saab seda ka ise muuta. Kas vastused sellele küsimusele on soome ja eesti ühiskonnas erinevad? Võiks arvata, et on, sest rahvuslik ajaloomüüt on erinev. Soome müüdis on samuti tähtsal kohal Teise maailmasõja sündmused, kuid neid tõlgendatakse teises võtmes - soomlased ise võtsid oma saatuse enda kätte.

Eesti naiste elulugudes puudutatakse minimaalselt küsimust, kas inimene oleks võinud ise oma elukäigus midagi muuta. Veel vähem küsitakse, kas oleks võinud või kas oleks tulnud ennast muuta. Soome naiste elulugudes on need kesksed teemad. Kui midagi ei saa muuta, on kahetsemine mõttetu. Kui 'saatuse' mõistel on kollektiivses tajus tugev roll, peaks kahetsemise olla haruldane nähtus. KL vanim kirjutaja ütlebki:

(41) Kuna ma ei ole olnud täiel määral oma saatuse juhtija, siis ei saa mul olla ka midagi kahetseda (KL 1997: 11; snd 1923). 


\section{Leena Huima}

Eesti vanem põlvkond (enne Teist maailmasõda või selle alguses sündinud) annab oma elulugudes päris harva hinnangu oma elule ja isiksusele. Kui midagi öeldakse, on see tavaliselt ma ei kahet$s e$, mõnikord täiendatud ütlusega tahtsin põleda, mitte vinduda. Oma iseloomu rolli seletavad autorid noomides oma liigset ausust ja headust. Kui midagi on viltu läinud, on tegemist ebaõnne, mitte isikliku veaga:

(42) Kokkuvõtteks võin ütelda, et vaatamata ebaõnnestunud abielule, mis kestis küll ikkagi pikka aega, ei kahetse ma midagi oma elus (NK 1997: 197; snd 1941).

(43) Ei, ma ei ole elanud halba elu. Tahtsin põleda, mitte vinduda. Ma ei tahtnud valetada ja ei taha seda ka praegu. Riivab hinge kogu möödunu sopaga plätserdamine. Keegi midagi ei analüüsi peatähtis, et saaks süüdistada (NK 1997: 139; snd 1936).

(44) Olen mõnikord mõelnud, et miks minu elu on nii vilets olnud. Kas tõesti vanemate patud nuheldakse laste kätte? [---] Oma arust tegin ma kõik selleks, et elada normaalset ja õnnelikku elu. Minu loomuses on liiga palju hellust, hoolitsust, ausust, edasipü̈̈llikkust ja optimismi (NK 1997: 120; snd 1934).

(45) Töötasin koolis kokku 32 aastat. Rõõmupäevi oli rohkem kui murehetki. Ma ei ole midagi kahetsenud ja kui tuleks uuesti alustada, valiksin taas õpetaja elukutse. Loomult olen liialt kohusetruu, aus ja täpne. Ma ei ole tahtnud valetada ega vinduda, vaid elada põledes. (EE I 2000: 484; snd 1925)

Seksielulugude kogumiku (KL) aluseks väljakuulutatud võistluse üleskutse tekstis toodi sissejuhatavaid küsimusi, millest üks oli: „Kas on midagi, mida oleksite tahtnud oma elus teisiti teha?" Niisiis lausa manitseti autoreid vastama ka sellele küsimusele. Üks autoritest tunnistabki oma patud väga dramaatiliselt üles:

(46) Kui ma nüüd süvenesin oma minevikku, siis pidin andma endale päris mitmes mõttes päris madala hinnangu. Mis seal aidata: olen olnud üks suuremat sorti suli. Olen olnud paadunud joodik, liiderdaja, pettur, valetaja, teeskleja, teise inimese järelt nuhkija, abielurikkuja, silmakirjatseja, keerutaja, oma vanemate vihkaja. Olen teinud kõike seda, mida Kümne Käsu järgi teha ei tohiks (KL 1997: 149; snd 1935). 
Siiski on ka KL-s tavaliselt samasugused hinnangud kui teisteski kogumites, kuigi autorite mälestused on sageli väga valusad:

(47) Kas ma midagi kahetsen? Kui saaksin elu uuesti alata, oleksin ju samast korralikust valedeta kodust ja usaldatav, niisiis kindlasti teeksin kõik samuti (KL 68:snd 1925).

Soomlaste ja eestlaste vahe on märgatav. Erinevas vanuses soomlased arutlevad oma elu üle, otsivad vigu ja küsivad endalt, kas midagi oleks pidanud teisiti tegema. Nad räägivad vabalt ka oma halbadest külgedest ja negatiivsetest emotsioonidest, samuti ka negatiivsetest kogemustest, millega seostub nt häbenemine:

(48) Syyllisyys painoi minua jatkuvasti. En rakastanut Jumalaa yli kaiken enkä kunnioittanut isääni, pelkäsin kyllä (SN: 19; snd 1914).

Tundsin ennast kogu aeg süüdlasena. Ma ei armastanud Jumalat üle kõige ega austanud oma isa, kuigi kartsin teda küll.

(49) Rukoilin hartaasti: Jumala, kasvata minusta hyvä opettaja. Sitä rukousta jatkoin ja jatkoin ja kadehdin kaikkia taitavia opettajia. Mutta minkä Jumalakaan minulle mahtoi, kun monta tärkeää edellytystä tuntui puuttuvan (SN: 20; snd 1914).

Palvetasin hardalt: Jumal, tee mind heaks õpetajaks. Seda palvet kordasin pidevalt ja kadestasin salaja kõiki osavaid õpetajaid. Aga kuidas oleks võinud mind isegi Jumal aidata, kui mitu tähtsat eeldust puudusid.

(50) Katkeruutta vastaan pyrin eniten taistelemaan. Se on muodostunut minulle peikoksi. Kateellinen tunnustan olevani. Eniten kai kadehdin toisten älyä, oppimishelppoutta, optimistisuutta ja iloisuutta (SN: 147; snd 1941).

Kõige rohkem püüan võidelda kibestumise vastu. Sellest on saanud mulle tont. Tunnistan, et olen kade. Kõige rohkem vist kadestan teiste aru, õppimisvõimet, optimismi ja rõõmsameelsust.

(51) Särmät ovat hioutuneet vuosien saatossa. Mutta yhä niitä on. (SN: 162; snd 1940)

Aastad on mind lihvinud. Aga siiski on mõni terav serv alles.

(52) "Minä olen kuule ajatellut koko ajan ja yrittänyt puhua, enää en jaksa mitään. Sinuun ei tehoa kertakaikkiaan mikään." Huusin ja aloin hakata miestä henkarilla. Jos kädessäni olisi sattunut 


\section{Leena Huima}

olemaan puukko, olisi sekin voinut heilahtaa, sanat tuntuivat riittämättömiltä. En yhtään ihmettele, jos joku tappaa toisen, kun mikään muu ei tehoa, kun koko ajan käy ärsytyskello vieressä (SN: 108; snd 1931).

"Tead, ma olen kogu aeg püüdnud aru saada ja rääkida, enam ei jaksa. Sind ei liiguta miski." Karjusin ja hakkasin meest riidepuuga peksma. Oleks mul olnud nuga käes, oleks ka see võinud teda tabada, tundus et sõnadest ei piisa. Ma ei imesta, kui keegi teise ära tapab, kui miski muu ei aita, kui närvikell heliseb kogu aeg kõrva ääres.

(53) Minua hävetti suunnattomasti, kun tallustelin paljain jaloin pölyistä maantietä leipäpussi kädessä, isä taas edellä nuoren lehmän kanssa. Lehmä hyppeli ja tanssi innoissaan, niin kuin vain härillään oleva lehmä osaa (SN: 125; snd 1937).

Tundsin suurt häbi, kõndides paljajalu mööda tolmust maanteed, leivakott käes, isa noore lehmaga kõige ees. Lehm hüples ja tantsis rõõmsalt, nagu ei oskagi keegi muu kui lehm, keda pulli juurde viiakse.

Üks NK autoritest, sündinud 1928, on erand vanema põlvkonna hulgas - ta kirjutab, et ta ei taibanud ennast muuta:

(54) Mina olin juba loomult uhke - abielludes olin arvanud, et kõik läheb nii, nagu MINA olen mõelnud, sest see on ju õige. Et ennast muuta, seda ma ei taibanud (NK 1997: 79; snd 1928).

Nooremad eesti autorid seevastu puudutavad neid teemasid. 1950. aastatel sündinud NK autoritel ilmuvad elulugudesse küsimärgid, just nimelt moraalsete või elukäigule hinnangut andvate teemade puhul. Varasemad põlvkonnad kasutavad retoorilist küsilauset üliharva; peaaegu ei kasutatagi. Näiteks:

(55) Olen ma siis kedagi õnnelikuks teinud? Kui ei, siis kas on viga minus või hoopis selles, et pole parimat minus üles leitud? (NK 1997: 255; snd 1954.)

Abielu ebaõnnestumine ei ole enam saatus, vaid põhjus on selles, et ise ei osanud:

(56) Naine on ju see, kes määrab kodusoojuse, ju ma siis olin liiga rahulolematu ega suutnud leppida asjadega, mida ma muuta ei saanud. Ma tõepoolest tahtsin abielus olla ja tahtsin ka õnnelik olla. Ju ma siis ei osanud (NK 1997: 260; 14; snd 1954). 
Teine sama põlvkonna autor kasutab sõna südametunnistus, mida varasemate põlvkondade autoritel ei leidu. Tema arutelud on väga põhjalikud:

(57) Kui elu viltu veab, tuleb põhjusi ja vigu otsida enda juurest (NK 1997: 238; 13; snd 1958).

(58) Veel ootaks elult veidi rohkem hingerahu. Üldiselt peetakse mind igaveseks naljavennaks ja seda ma enamasti olengi. Aga tegelikult vaevab mind pidevalt südametunnistus - äkki ma teen kogu aeg valesid asju. Ma ei tea, kas mul on üldse õigus paremat elu tahta (NK 1997: 250; 13; snd 1958).

(59) Kõige raskem probleem, mis mind vaevab, on see, et ma ei saa kuidagi selgust kahe väite vahel. Üks ütleb - kõiges, mis inimesega halba juhtub, on ta ise sü̈̈di ja teine - ärge sü̈̈distage asjatult ennast. Kui inimene näiteks praegusel ajal autopommi ohvriks langeb, kuigi ta on vaid juhuslik mööduja, kas ta on siis ise süüdi? Kui mees naist peksab, siis on ka muidugi naine süüdi, mis ta siis läks sellisele, aga võib-olla on ta siiski väga hea, õrn ja kannatlik naine? Kas ülekohut maailmas tõesti ei olegi? (NK 1997: 251; snd 1958.)

Ka selle teema puhul sarnanevad - vanusele vaatamata - väliseestlased nooremale põlvkonnale. 1921. aastal sündinud Kanada eestlanna:

(60) Jäänud on ka elu jooksul selgeks saanud mõisted „hea” ja „halb”. Enesega rahulolu on võrdlemisi raske saavutada. Siiski peaks selleni jõudmine vahelgi võimalik olema, kui teeme igas olukorras oma parima (EE I 2000: 261; snd 1921).

\section{Õnne ja enese otsimine}

Selles osas vaatleme, mida eesti ja soome naised oma elus tähtsaks peavad. Kuidas tekib õnn? Kes on õnnelik inimene? Kas inimene üldse saab oma saatusega rahul olla?

Eesti elulugudes on sõna õnn ja selle tuletised (nt õnnelik) suhteliselt harilikud, kuigi elukogemused on soomlaste omadest traagilisemad. Eesti eluloo kirjutajatel on õnne tekitavad tegurid ligikaudu alati samad: lapsed, lapselapsed - eriti nende edukus ja andekus ning korralik käitumine -, korter, vesi ja soojus: 


\section{Leena Huima}

(61) $\mathrm{Mu}$ mõtted on pidevalt lastelaste, oma laste ja koolilaste juures. Kas see pole määratu, üleskaalumatu õnn? (NK 1997: 159; snd 1938.)

(62) Mulle tundub, et olen osanud oma igapäevases, vaikselt ja rahulikult kulgenud elus õnne ära tunda, teda hoida ja hinnata. Eks ole ju see õnn - elada kogu elu vanemate poolt rajatud ilusas kodus, ümbritsetuna perekonnast ja paljudest headest sõpradest (EE II 2000: 189; snd 1935).

(63) Kõrgele eale vaatamata elan veel. Mul on kolm tublit poega, 10 lapselast ja 5 lapselapselast. Ei ükski minu täiskasvanud järglastest ole suitsetaja, alkohoolik ega narkomaan. Enda teada olen üks onnnelikumaid eesti emasid. (EE I 2000: 80; snd 1911)

(64) Ajad on läinud - head ja halvad. Mälestusi tõrvates valetaksin. Ajad olid teised ja inimesed olid teised. Välismaalt toiduabipakke ei oodatud. Näljas me ei olnud. Minu laps räbalates ringi ei jooksnud. 1. septembril 1973. a. läks tütar esimesse klassi. Küünlapäeval kolisime mugavustega korterisse - sain sooja vee, gaasipliidi... Olime õnnelikud (NK : 139; snd 1936).

(65) Olen oma elujärjega praegu väga rahul. Poisid on ehitanud maja keldrisse kaevu, vesi tuleb kraanidest nii kööki kui sauna. Kastmisvee saame suvel pumbaga jõest. Naabritega, kellega hakkasime suhtlema juba algusaastatel, saame hästi läbi ja välja on kujunenud oma väike sõpruskond. Eriti uhke ja südamlik tunne on hinges riigipühadel, kui maja katusel lehvib sinimustvalge riigilipp. Ainuke mure, mis mind praegu kurvastab, on see, et meil pole veel lastelapsi (EE II 2000: 208; snd 1935).

(66) Suur rõom on minu praeguses elus, kui minu lapsed ja lapselapsed minu söögilaua ümber on kogunenud. Panen laua peale kõik, mis mul panna on, mõtlemata, kas tulen pärast endaga läbi (NK 1997: 119; snd 1934).

Perekonnasidemete tugevust näitab ka see, et eestlased kirjutavad reeglipäraselt oma elulugudes oma vanemate surmast ja nende lahkumise raskusest. See ongi ainus teema, mille puhul on tavaline väljendada ka emotsioone:

(67) Siis suri äkitselt minu armas ema ja see üleelamine oli suurim kõigist eelmistest. Tundsin, et minu jaoks jäi maailma tühi auk, mida keegi ei suuda täita (NK 1997: 157; snd 1939). 
(68) Minu ema maine rännutee lõppes 1985. aastal. Ta oli elanud neljateistkümnes kodus-elupaigas ja 1985. aasta märtsis matsime ema viimsele puhkepaigale, isa kõrvale. Lõppenud oli kahe kalli inimese maine rännutee, mis oli nooruses nii looduslähedaselt rõõmus ja vananedes vägivaldselt okkaliseks immutatud nagu paljudel eesti emadel ja isadel (EE II 2000: 182; snd 1935).

Soome naiste õnnetegurid paistavad olevat osalt vastupidised. Neile on tähtis enese otsimine ja endaga tutvumine, millega seostub vaimse ruumi otsimine ja perekonnasidemetest vabanemine. Mitmes eluloos ei ole sõnagi vanemate surma kohta. Emad räägivad, kuidas neil on lausa moraalseks kohustuseks lapsed oma põllepaeladest lahti lasta. Nii autori enda vabanemisprotsessi kui laste kodust lahkumise puhul kasutatakse sõda, mässu ja võitlust tähendavaid sõnu, nt kapina ja taistelu:

(69) Äitini oli erittäin voimakas ja lujatahtoinen. Hän järjesteli asioitani tietämättäni. Aikuisena jouduin taistelemaan hänen kanssaan, ettei hän olisi puuttunut elämääni (SN: 143; snd 1941).

Mu ema oli tubli ja väga tugeva tahtejõuga. Ta korraldas mu asju mu enda teadmata. Täiskasvanuna pidin temaga võitlema, et ta mu elu ei segaks.

Võrreldagu eelmist näidet järgmise eesti näitega:

(70) Möödus aasta või kaks ja see noormees võttis mind vägisi. [---] Ema soovitas mul selle noormehega abielluda, kuna tema teadis, et ta armastab mind. [---] Minu abielu polnud õnnelik, sest ma polnud selleks valmis. Hakkasin südames vihkama oma meest. Ka seks ei köitnud mind. Mees aga nõudis seda. Pöördusin abi saamiseks arsti (seksuoloogi) poole. Ema tahtel tuli elada (KL 1997: 183; snd 1939).

Ka abikaasa ja kogu pere vastu tuleb soomlasel võidelda; tegemist on moraalse kohustusega, nagu näitab modaalväljend käytävä se oli. Seletus jos ei olisi tullut Asiaa, olisi se käyty jostain muusta viitab konventsioonile, et elus saabub teatud hetk, kui mässu enam edasi lükata ei saa. Samale viitab ka näide (72):

(71) Todellinen henkien taistelu käytiin perheessämme kymmenen vuotta sitten. Jos ei olisi tullut Asiaa, olisi se käyty jostain muusta. Käytävä se oli, olin liian kauan ollut liian sopeutuvainen. Mieheni osti kesämökkipalstan. Jumalani, että minä suutuin (SN: 157; snd 1940). 


\section{Leena Huima}

Tõeline vaimuvõitlus käis meie peres kümme aastat tagasi. Kui ei oleks tulnud see Asi, oleks põhjus olnud mingi teine. Aga tulema see pidi, sest liiga kaua olin muganenud. Mees ostis suvilakrundi. Issand, et see mind vihastas (SN: 157; snd 1940).

Üks võidu dimensioonidest on arusaamine sellest, et inimene, eriti naine, ei tarvitsegi olla tubli. Tal ei ole vaja kõigega hakkama saada:

(72) Kolmenkymmenenviiden ikävuoden jälkeen huomasin itsessäni uusia piirteitä. Halusin enemmän aikaa itselleni. [---] Halusin opiskella. Käydä teatterissa, konserteissa, halusin hoitaa itseäni. Ay-toiminta kiehtoi. Kyselin itseltäni, mihin minusta on ja mitä nämä uudet ajatukset aiheuttavat perheelleni. Oli minun kapinani aika (SN: 187; snd 1949).

Pärast 35. eluaastat leidsin endas uued jooned. Tundus, et vajan rohkem aega endale. [---] Tahtsin õppida, käia teatris, kontsertidel, tahtsin enda eest hoolitseda. Mind huvitas ametiühingutegevus. Küsisin endalt, mis on mulle omane ja kuidas need uued ideed mu perekonnale mõjuvad. See oli minu mässu aeg.

Enda leidmine ja endaga tutvumine toovad soomlaste sõnul rõõmu ja õnne:

(73) Nyt kun olen oikeutettu ihan oikeaan vanhuuseläkkeeseen, olen näin veteraanina valmis kertomaan, ettei se työstä luopuminen sittenkään niin vaikeaa ole. Onhan ilo saada vihdoinkin etsiä uusia tai paneutua vanhoihin harrastuksiin, löytää uusia vivahduksia omasta, ikäihmisen elämästään, jopa omasta luonteestaankin. Ja ennen kaikkea, saa olla väsynyt, saa levätä, saa jopa tehdä tyhmyyksiä ilman, että pelkää, mitä toiset sanovat (SN: 43; snd 1924).

Nüüd, kui mul on lausa õige ja enda teenitud vanaduspension, olen kui veteran valmis ütlema, et ega see tööst loobumine siiski nii raske ole. On ju rõõm saada viimaks otsida uusi harrastusi või siis endisile elu sisse puhuda, leida uusi nüansse oma vanainimese elust, isegi oma iseloomust. Ja eelkõige, tohib olla väsinud, tohib puhata, tohib isegi lollusi teha, ilma et kardaks, mis teised selle kohta ütlevad.

(74) Nyt olen nelikymppinen, omasta mielestäni nuori. Vasta nyt tunnen löytäneeni oman itseni. En haikaile ja tavoittele kuuta 
taivaalta. Tiedän, mitä haluan, mitä osaan ja mitä haluaisin tehdä (SN: 188; snd 1949).

Nüüd olen neljakümnene, mu enda silmis noor. Alles nüüd tunnen, et olen ennast leidnud. Ma ei igatse ega taotle kuud taevast. Ma tean, mida ma tahan, mida ma oskan ja mida ma teha tahaksin.

Soomlased kasutavad ka väljendit elää omaa elämäänsä 'oma elu elama'. Vastavat väljendit eesti autoritel ei esine:

(75) Lähellä alkoi kukkua käki, sen helkähtelevät kukunnat kuuluivat selkeinä tyynessä illassa. Kuuntelin sitä miltei hengitystäni pidättäen, kuinka paljon se kukkuisi minulle vuosia, olisivatko ne parempia? Sen saisin tietää vain elämällä nuo vuodet, ja huomisesta lähtien alkaisin elää omaa elämääni (SN: 86-87; snd 1927).

Lähedal hakkas kägu kukkuma, tema hele hääl kuulus selgelt vaikses õhtuilmas. Kuulasin teda hinge pidades: mitu aastat ta mulle kukub, kas need on paremad? Seda võiksin teada ainult need aastad läbi elades, ja alates homsest päevast hakkasin oma elu elama.

Kuigi saatuseaja põlvkond ei räägi eneseotsimisest, on see teema noorematele tuntud. Ka väliseestlased räägivad sellest. Ühelt poolt otsivad nad eestlusega seotud identiteeti ja tahavad sellepärast tutvuda oma suguvõsa minevikuga, teiselt poolt otsivad nad oma isiklikku mina:

(76) See on vist lugu ühe naise võitlusest iseeneseks jäämise eest. Kahtlesin, kas seda üldse kirjutada. Aga mul pole lapsi, ja võibolla jääb sel kombel minust midagi järele (EE II 2000: 282; snd 1938; elanud Inglismaal ja Hispaanias).

(77) Peame otsima lõnga, mis ühendab. Alles siis tunneme ennast. Olen uhke oma päranduse üle. Oskan eesti keelt ja olen loonud ühenduse vanemate minevikuga. Olen näinud nende elukohti, olgu et kümneid aastaid hiljem. Süda on kerge (EE II 2000: 359; snd 1945; elab Austraalias).

(78) Arvan, et minu iseseisvumine langeb Eesti Vabariigi taasloomise aega. Need on kuidagi seotud, see vabanemine ja sisemine tunne, et miski peab muutuma ja midagi tuleb muuta. Ühel hetkel ütlesin endale: ma ei pea elama elu, mis mulle ei sobi ja teeb 


\section{Leena Huima}

haiget, kus ma pole õnnelik ja kannatan olukordade käes, mida ma muuta ei saa. Ma ei pea, sest see on minu elu! Tahan olla ise! (NK 1997: 261; snd 1954.)

(79) Ma ei palvetanud, aga kord Jumal rääkis minuga. Ma olin siis rongis, kui Ta hüüdis mind ja ütles: "Sirje, see ongi vaikne õnn." Mida ma need rasked kuud endas seedisin, ei oska täpselt öelda. Aga sel ajal panin aluse sellele, kes ma praegu olen (EE II 2000: 374; snd 1949).

EE-s leidub ka kaks 1970. aastatel sündinud naist. Nad ei küsi, vaid teavad täpselt, missugused nad ise on ja mida nad elult tahavad:

(80) Olen tüüpiline oma aja inimene. Mind on paljuski mõjutanud Nõukogude aeg, mil olin laps ja kooliõpilane, aga sama palju ka "ärkamisaeg", mis jäi varasesse noorusesse, ning praegune turumajanduslik maailmavaade, mis sunnib ennast kokku võtma ning tõsiselt tuleviku peale mõtlema. [---] Pü̈̈an ise olla selline, nagu tahaksin näha inimesi enda ümber. Pü̈̈an maailma muuta ilusamaks, niipalju kui see on minu võimuses (EE II 2000: 482; snd 1970).

(81) Minus on edukalt ühinenud konservatiivsed ja liberaalsed jooned, püüan olla salliv kõigi ja kõige suhtes, kuigi see alati päris hästi välja ei tule. Loodan ennast teostada valitud erialal, kuigi olen mõelnud, kas ma oma mässumeelse hinge poolest üldse sobin kooliõpetajaks. Pean end aga üldiselt õnnelikuks inimeseks ja leian, et olen elult palju saanud ja pü̈̈an sama palju ka vastu anda (EE II 2000: 504; snd 1977).

KL-s on üks aastal 1980 sündinud autor. Tema eluloo struktuuris kajastub postmodernsele ajale omane pluralism, hetkelisus ja kildlikkus:

(82) See oli minu lugu, mis on küll traagiline, aga lõpp tundub minevat heaks. See kõik on andnud mulle eluks hea põhja alla. Olen osa traagilisi sündmusi kirjutamata jätnud, kuna siis veniks kogu asi väga pikaks ja tüütavaks. Elus tuleb osata nautida just seda hetke, mis on, sest sa ei või iial teada, mida järgmine päev tuua võib (KL 1997: 373; 1980). 


\section{Järeldused}

Eesti naised, eriti 1920. ja 1930. aastatel sündinud, räägivad oma elulugudes inimese elukäigust kui mingi välise jõu poolt ettemääratud saatusest. Nad tõlgendavad oma elu eesti ühiskonna praegusele ajalookäsitlusele vastavalt. Kirjutajate isikliku elukäigu sündmustest olid kõige tähtsamad Teise maailmasõjaga seotud dramaatilised, ootamatud pöörded, mis ületasid inimese mõistmisvõime, mida ei saanud peatada ega tõrjuda. Okupatsiooni ajal olid inimeste võimalused oma elu mõjutamiseks väikesed. Saatuse mõistet kasutati kollektiivse ajalootaju struktureerimiseks.

Soome naiste eluloolist materjali on selles uurimuses vähe, mistõttu ei saa võrdlustulemusi pidada päris kindlaks. Siiski on päris ilmne, et soomlased räägivad saatusest teisiti. Nad arutlevad eestlastest märgatavalt rohkem küsimuse üle, millepärast kellegi isiklik elu läks nii nagu ta läks. Põhjusi otsitakse kõige rohkem endast: küsitakse, mida mina oleksin pidanud teisiti tegema või kuidas mina oleksin saanud asju muuta. Ka sellel on ilmne seos ühiskonna kollektiivse ajalootõlgenduse ja rahvusliku müüdiga.

Saatus on eesti naiste elulugudes väga kaugele personifitseeritud ja tuletab meelde kristluse Jumala-kujundit. Traditsionaalne katekismuse Jumal on siiski kõigeväeline, kaitsev ja armastav; eesti naiste elulugude Saatus on juhuslikum ja mehhaanilisem.

Soome naised väljendavad rohkem usku sellesse, et inimene on võimeline oma elukäiku ja oma keskkonda muutma ning ise sisemiselt muutuma. Muutmine ja muutumine on moraalselt kõrgelt hinnatud, isegi kohustuslikud. Endale ja keskkonnale mõjumine tuleb esile soomlastel ja eesti noorematel autoritel. Viiteid on ka sellest, et jumalausk ja aktiivne mõjuvõimaluste otsimine käivad mingil määral koos.

Väliseestlaste, eesti noorema põlvkonna ja soomlaste kirjutiste vahel on märgatavalt vähem erinevusi kui eesti vanema põlvkonna ja soomlaste vahel. Tulemust võiks pidada mingil määral üllatavakski. Vaimne õhkkond ja kultuurilised konventsioonid olid Eesti Vabariigi esimesel perioodil tolleaegse Soomega suhteliselt sarnased, sõjajärgsel põlvkonnal aga täiesti erinevad (kuigi välismaalt vaadates on raske hinnata eesti põrandaaluse kultuuri tegelikku mõju). Siiski sarnaneb noorem põlvkond rohkem soomlastega, 


\section{Leena Huima}

ka vanemate soomlastega. Ka väliseestlased tõlgendavad oma elukäiku rohkem soomlaste moodi, vanusele vaatamata ja kodueesti samaealistest erinevalt.

\section{Allikad ja kirjandus}

EE I 2000 \& EE II 2000 = Hinrikus, Rutt (koost). Eesti rahva elulood. Sajandi sada elulugu kahes osas. Tallinn.

EKG II 1993 = Eesti keele grammatika. Osa 2. Süntaks. Tallinn.

Eesti kirjakeele seletussõnaraamat 1997. V. Tallinn.

Kivimäe, Jüri 1999. Re-writing Estonian history? National History and Identity. Approaches to the Writing of National History in the North-East Baltic Region Nineteenth and Twentieth Centuries. Studia Fennica Ethnologica 6. Tampere, lk 205-212.

KL 1997 = Karusoo, Merle (koost). Eesti elulood. Kured läinud, kurjad ilmad. Tartu.

Kõresaar, Ene 1999. Pauliina Latvala „Soomlase elu kujutamine pärimuslikus ajaloos". Märkused ja kommentaarid. Mäetagused 11. E-väljaanne: http://haldjas.folklore.ee/ tagused/nr11/komm2.htm.

NK 1997 = Annuk, Eve (koost). Eesti elulood. Naised kõnelevad. Tartu.

Park, Andrus 1999. Lessons of national history in Estonian security thinking, 1991-April 1994. National History and Identity. Approaches to the Writing of National History in the North-East Baltic Region Nineteenth and Twentieth Centuries. Studia Fennica Ethnologica 6. Tampere, lk 213228.

Raun, Toivo U. 1987: Estonia and the Estonians. Stanford, California. Siikala, Anna-Leena 1992. Myyttiset metaforat ja samanistinen tieto. Metafora. Ikkuna kieleen ja kulttuuriin. Suomi 162. Helsinki.

SN 1992 = Piela, Ulla (toim). Satasärmäinen nainen. Elämäkertoja. Kalevalaisten Naisten Liiton julkaisuja. Kansanelämän kuvauksia 35. Tampere. 